\title{
Temporary Measures on Bankruptcy: Alternatives to the Moratorium on Act 37/2004 in Resolving Indonesian Bankruptcy During the COVID-19 Pandemic
}

\author{
Cintya Sekar Ayu Permatasari \\ Faculty of Law, Universitas Gadjah Mada, Sleman, Yogyakarta, Indonesia \\ Email: cintyasekarayup@mail.ugm.ac.id \\ ORCID Link: https://orcid.org/0000-0003-4608-9744
}

Octa Nadia Mellynda

Faculty of Law, Universitas Gadjah Mada, Sleman, Yogyakarta, Indonesia

\section{Citation:}

Permatasari, C. S. A. \&

Mellynda, O. N. (2021).

Temporary Measures on

Bankruptcy: Alternatives to the

Moratorium on Act 37/2004 in

Resolving Indonesian

Bankruptcy During the COVID-

19 Pandemic, Lex Scientia Law

Review, 5(2), 19-40, doi:

https://doi.org/10.15294/lesrev.

v5i2.50600

\section{History of Article}

Received: October 5, 2021

Revised: November 12, 2021

Accepted: November 19, 2021

(C) The Author(s)

\section{(c) (i) 90}

This work is licensed under a Creative Commons Attribution-NonCommercialShareAlike 4.0 International License.

All writings published in this journal are personal views of the authors and do not represent the views of this journal and the author's affiliated institutions.

\begin{abstract}
The high number of bankruptcies in Indonesia, which increased to $54 \%$ in the pandemic era, had negative impacts on the economic ecosystem in Indonesia. A regulation is needed that can reduce the number of bankruptcies, in which the moratorium of Act 37/2004 is a discourse that will be predicted as the main solution. The moratorium of Act 37/2004 with its weaknesses has been rejected by many parties, so this research will offer a more appropriate alternative solution in the form of setting temporary measures on bankruptcy. This study seeks to describe the urgency and prospects of the presence of temporary measures on bankruptcy in Indonesia and recommend the regulation and implementation of temporary measures on bankruptcy in Indonesia. This legal research is normative legal research with data obtained from library research analyzed descriptivequalitatively. The results of the study indicate that the moratorium of Act 37/2004 does not provide fair benefits for debtors and creditors in resolving bankruptcy problems so that it will actually hinder investment in Indonesia. Temporary measures on bankruptcy is an alternative that fills the absence of law in Indonesia
\end{abstract}


Lex Scientia Law Review published by Faculty of Law, Universitas Negeri Semarang, Indonesia in collaboration of UKM Lex Scientia. Published biannually every May and November. regarding provision to bankruptcy relaxation. These measures provide fair benefits for both parties while still being able to file for bankruptcy but with a certain threshold and stimulus. Seeing the success of temporary measures on bankruptcy in various countries in reducing the number of bankruptcies, Indonesia needs to immediately implement the same thing in the Peraturan Pemerintah Pengganti Undang-Undang (PERPU).

\section{KEYWORDS}

Bankruptcy; Measures; Moratorium; Regulation; Stimulus

\section{INTRODUCTION}

The COVID-19 pandemic has impacted not only the health sector but also the economic sector in Indonesia. One example is the result of social restrictions such as the PSBB and PPKM policies, which caused some companies to reduce their operations, resulting in a decrease in revenue. Data from the Central Statistics Agency stated that $17.31 \%$ of companies in the accommodation, food and beverage sector and $16.30 \%$ of service sector companies temporarily stopped operating due to the COVID-19 pandemic ${ }^{1}$. The operational restrictions for companies also has an impact on the decline in the income of each company. This is proven by the phenomenon during third quarter of 2020, $66.09 \%$ of companies experienced a decrease revenue, while only $10.43 \%$ of companies experienced an increase income. ${ }^{2}$ The companies income decline during COVID-19 also has an impact on the companies inabilities to pay debts to creditors.

The inability to pay debts is one of the most highlighted issues during the COVID-19 pandemic leads to bankruptcy Chairman of the Indonesian Association of Curators and Administrators (AKPI), Jimmy Simanjuntak, stated that the current COVID-19 pandemic situation has caused a number of companies to experience economic difficulties and even some companies may not be able to maintain their business and even go bankrupt ${ }^{3}$. In fact, during the COVID-19 pandemic, the number of applications for postponement of payment obligations (PKPU) and bankruptcy cases in the Commercial Court

\footnotetext{
${ }^{1}$ Sofia Ayuni, dkk, Analisis Hasil Survei Dampak COVID-19 Terhadap Pelaku Usaha Jilid II, Badan Pusat Statistik Republik Indonesia, Jakarta, 2020, hlm. 4.

${ }^{2}$ Ibid. hlm. 11.

${ }^{3}$ Fitri Novia Heriani, "Perkara Kepailitan dan PKPU Meningkat 50 Persen Selama Pandemi", Hukum Online, 31 Agustus 2020, diakses dari https://www. hukumonline.com/berita/ baca/lt5f4ce322c779b/perkarakepailitan-dan-pkpu-meningkat50-persen-selama-pandemi/.
} 
increased ${ }^{4}$. This fact is supported by data obtained from the Case Investigation Information System (SIPP) at 5 (five) Commercial Courts in Indonesia, Medan, Semarang, Surabaya, Makassar and Central Jakarta Commercial Courts, show that compared to 2019 (before the COVID-19 pandemic, 19) there was an increase in PKPU and Bankruptcy applications 154 cases, as well as cases that were granted an increase of 55 cases in 2020 (the beginning of COVID-19 pandemic). ${ }^{5}$

Bankruptcy is a court decision that results in general confiscation of all assets of the debtor declared bankrupt, both existing assets and those that will exist in the future. ${ }^{6}$ Meanwhile, a bankrupt is the inability of the debtor to pay his debts that have matured.7 In Indonesia, bankruptcy is regulated in Act Number 37 of 2004 concerning Bankruptcy and Suspension of Debt Payment Obligations (hereinafter referred to as "Act 37/2004"). Act 37/2004 does not provide an explicit definition of bankruptcy. Article 1 point (1) only explains that bankruptcy is a general confiscation of debtor assets whose management and settlement are carried out by the curator under the supervision of a supervisory judge.

In relation to the issue of bankruptcy, the Indonesian Employers Association (APINDO), in a press conference held on Tuesday, September 7, 2021, stated its urgency to the government to immediately issue a Government Regulation in Lieu of Law (PERPU) moratorium on Act 37/2004 concerning PKPU and Bankruptcy. ${ }^{8}$ According to APINDO, during the current COVID-19 pandemic, the number of company bankruptcy cases..$^{9}$ is increasing and are already at an unhealthy level. Based on data compiled by APINDO, during the COVID-19 pandemic, there were 1,298 cases of PKPU and bankruptcy. The number of PKPU and bankruptcy cases increased

\footnotetext{
${ }^{4}$ M. Rizaldi H, "Penundaan Kewajiban Pembayaran Utang Untuk Mencegah Debitur Pailit Akibat Pandemi COVID-19 Berdasarkan Hukum Kepailitan", Dinamika Jurnal Ilmiah Ilmu Hukum, Volume 27 Nomor 2, 2021, hlm. 284.

${ }^{5}$ Siregar Setiawan Manalu Partnership, "Mempertanyakan Kegentingan Moratorium PKPU”, SSMP, 3 September 2021, diakses dari https://www.ssmp.co/assets/pdf/mempertanyakan-kegentinganmoratorium-PKPU.pdf.

${ }^{6}$ Ulang Mangun, Syprianus Asiesteus, \& Nevey Varida A, Kepailitan dan Penundaan Kewajiban Pembayaran Utang Studi Hukum dalam Rangka Penyusunan Naskah Akademik Rancangan Undang-Undang Nomor 37 Tahun 2004, Badan Penelitian dan Pengembangan Hukum dan HAM Kementerian Hukum dan HAM Republik Indonesia 2017, Jakarta, 2017, hlm.1

${ }^{7}$ Ibid.

${ }^{8}$ Maesaroh, "Asosiasi Pengusaha Desak Jokowi Terbitkan Perppu Moratorium PKPU”, Katadata.co.id, 7 September 2021, diakses dari https://katadata.co.id/maesaroh/berita/61377c61ba3e2/asosiasipengusaha-desak-jokowi-terbitkan-perppu-moratorium-pkpu.

${ }^{9}$ Ibid.
} 
compared to the 2018-2019 period, which was only 959 cases. APINDO also stated that the increase in bankruptcy cases was partly due to the ease of filing bankruptcy requirements. Another factor causing the rise of PKPU filings and bankruptcy according to APINDO is the absence of a submission limit so that the submissions can be done repeatedly.

Acknowledging APINDO's insistence on the issuance of the PERPU moratorium on PKPU and bankruptcy, the government currently admits that it is discussing and reviewing this proposal to prevent moral hazard or actions that could pose a risk of loss to other parties if the moratorium is implemented. This is because the moratorium discourse raises pros and cons for some parties. Some parties believe that this moratorium will only benefit debtors not for creditors. However, several parties also welcomed the moratorium discourse with a review note before the moratorium was implemented. Regarding this issuec, in this paper the authors analyze the extent to which the moratorium can be a solution by conducting comparative studies of other countries in dealing with bankruptcy problems during the COVID-19 pandemic. Many countries prefer to use Temporary Measures on Bankruptcy and have succeeded in handling bankruptcy problems, especially to reduce the number of bankruptcies during the COVID-19 pandemic. The focus discussion in this paper is first, is it true that the moratorium is a solution in reducing the number of bankruptcies in Indonesia during the COVID-19 pandemic era. Second, what is the urgency of Temporary Measures on Bankruptcy to reduce the number of bankruptcies in Indonesia during the COVID-19 pandemic era? And third, what are the prospects for setting up and implementing Temporary Measures on Bankruptcy in handling bankruptcy in Indonesia during the COVID-19 pandemic era?

\section{METHOD}

This study uses normative legal research method that focuses on examining applicable normative law. ${ }^{10}$ In this paper, the focus is on the Bankruptcy Relaxation Policy. The data collection technique used in this paper is document studies. The object of document study consists of primary, secondary, and tertiary legal materials. ${ }^{11}$ Primary legal materials are positive law, in this study the primary legal materials used are the Law of the Republic of Indonesia Number 37 of 2004 concerning Bankruptcy and Suspension of Debt Payment Obligations and the Regulation of the Financial Services Authority of the Republic of Indonesia Number

\footnotetext{
${ }^{10}$ Abdulkadir Muhammad, Hukum dan Penelitian Hukum Cet-1, PT Citra Aditya Bakti, Bandung, 2004, hlm. 52.

${ }^{11}$ Soerjono Soekanto, Pengantar Penelitian Hukum, Penerbit UI, Jakarta, 1986, hlm. 52.
} 
48/POJK.03/ 2020 jo. Regulation of the Financial Services Authority of the Republic of Indonesia Number 11/POJK.03/2020. Secondary legal material is an explanation of primary legal material, which in this study was obtained from the results of previous research and the work of the legal community (books, articles, and reports). Tertiary legal materials are materials that provide instructions/explanations on primary and secondary legal materials. In this study, tertiary legal materials in the form of the Legal Dictionary and the Big Indonesian Dictionary will be used. This legal research uses a statutory approach ${ }^{12}$ This legal research uses a statutory approach by examining the Law of the Republic of Indonesia Number 37 of 2004 concerning Bankruptcy and Suspension of Debt Payment Obligations, and a conceptual approach (conceptual approach) ${ }^{13}$ by studying the views in legal science in order to produce an understanding and legal concepts that are relevant to the problem under study. Analysis of the data in this study was carried out through qualitative methods, which resulted in a descriptive-analytical analysis. The data compilation and analysis used in this paper is deductive reasoning, which starts from general terms, points to specific conclusions.

\section{RESULT AND DISCUSSION}

\section{A. Moratorium Act 37/2004, is it a solution?}

Fundamentally, APINDO's proposal to urge the government to make PERPU a moratorium on Act 37/2004 is based on two things. First, the high number of bankruptcies during the COVID-19 pandemic and second, the increase in the bankruptcy rate during the COVID-19 pandemic was also triggered by weaknesses in Act 37/2004 such as the ease of filing requirements and many moreBefore proceeding with the analysis, the authors first describe the facts. First, concerning the number of bankruptcy applications during the COVID-19 pandemic. The data provided by APINDO at the press conference shows during the COVID-19 pandemic, there were 1,298 cases of PKPU and bankruptcy, which means an increase of 339 cases from 2018-2019.14 Meanwhile, based on the data obtained from the Case Tracing Information System (SIPP) at 5 Commercial Courts in Indonesia, PKPU and bankruptcy applications from 2017 to 2020 are presented in the following table:

\section{Tabel 1. Data SIPP tentang Kepailitan Tahun 2017-202015}

\footnotetext{
12 Johnny Ibrahim, Teori dan Metodologi Penelitian Hukum Normatif, Bayumedia Publishing, Malang, 2006, hlm. 30.

${ }^{13}$ Peter Mahmud Marzuki, Penelitian Hukum, Kencana, Jakarta, 2005, hlm. 95.

${ }_{14}$ Ibid.

${ }^{15}$ Siregar Setiawan Manalu Partnership, Loc.Cit.
} 


\begin{tabular}{|l|l|l|l|}
\hline Year & $\begin{array}{c}\text { Number of } \\
\text { Applications }\end{array}$ & Admitted & $\begin{array}{c}\text { End with } \\
\text { homologation }\end{array}$ \\
\hline 2017 & 168 & 76 & 18 \\
\hline 2018 & 191 & 56 & 6 \\
\hline 2019 & 285 & 104 & 11 \\
\hline 2020 & 439 & 169 & 66 \\
\hline
\end{tabular}

From the data above, compared to 2019 before the COVID-19 pandemic occurred, in 2020 applications for PKPU and bankruptcy cases increased by $54 \% x^{\prime}$. Therefore, it is true that the number of bankruptcy applications during the pandemic has increased sharply from the pre-pandemic period. Acknowledging the drastic increase in bankruptcy cases, the Chairman of APINDO, Hariyadi Sukamdani, stated that if PKPU and Bankruptcy cases continue to increase, the business climate in Indonesia will be disrupted, more companies will stop operating, and the number of unemployed will increase considering that many companies can quit because of bankruptcy. ${ }^{16}$ This high bankruptcy rate certainly has an impact not only on debtors but also on creditors. For debtors, as stated in Article 10 of Act 37/2004, as long as the decision on the bankruptcy application has not been declared, part or all of the debtor's assets can be requested for collateral confiscation or authority over the debtor's assets can be transferred to the curator, within the scope of supervision of the debtor's business management until the payment. When a debtor request for bankruptcy, the debtor has no full power over his assets. This can bring both immaterial and material losses to the debtor, even though the bankruptcy decision has not yet been declared. ${ }^{17}$ One example that illustrates how material and immaterial losses greatly affect debtors who are filed for bankruptcy is the case of PT Sentul City Tbk, which was sued for bankruptcy by the Bintoro family. At that time, the number of debt problems was even smaller than the company's assets. The bankruptcy application also caused the Indonesian Stock Exchange to suspend the shares of PT Sentul City Tbk temporarily. ${ }^{18}$ This makes PT Sentul City Tbk suffers material and

\footnotetext{
${ }^{16}$ Agus Sahbani, "Respons MA Terkait Rencana Moratorium PKPU dan Kepailitan", Hukum Online, 2 September 2021, diakses dari https://www.hukumonline.com/berita/baca/lt612fbd1f1bfc3/responsma-terkait-rencana-moratorium-pkpu-dan-kepailitan?page=all.

${ }^{17}$ Luthvi Ferbyka Nola, "Dampak Kemudahan Pengajuan Pailit di Masa Pandemik COVID-19", Info Singkat, Volume XII Nomor 18, 2020, hlm. 2.

${ }^{18}$ Ibid.
} 
immaterial losses, including for related parties such as consumers. As for the creditors, the bankruptcy petition has an impact on the authority to execute the mortgage object ${ }^{19}$. Based on Article 56 paragraph (1) of Act 37/2004, it is stated that the right of execution of separatist creditors holding mortgage rights against mortgages that are in the control of the debtor is suspended for a maximum period of 90 days (stay period) since the debtor is declared bankrupt. That is, during the period of suspension, the object of the mortgage is under the supervision of the curator. Second, regarding the ease of application for bankruptcy. There are 2 (two) requirements needed for bankruptcy application as regulated in Article 2 paragraph (1) of Act 37/2004, firstly the debtor has at least 2 (two) or more creditors and secondly debtor does not pay off at least one debt that is due and can be collected. The bankruptcy application will be granted if the two conditions based on Act $37 / 2004$ are proven simply. The requirements for applying for bankruptcy in Indonesia are much easier than the requirements for bankruptcy in several countries. $^{20}$ In addition, Act 37/2004 also does not recognize nebis in idem principle, which means that if an application for bankruptcy is rejected, it can be applied again. ${ }^{21}$ The weakness of Act 37/2004 also has an impact on creditors. Act 37/2004 states that creditors have the right to execute mortgages as if there was no bankruptcy. Regardless, Article 56 paragraph (1) of Act $37 / 2004$ provides a limitation in the form of the creditor's right of execution of the mortgage object being suspended for a maximum of 90 days after the debtor is declared bankrupt. This is where an inconsistency exists in the regulation, the authority to execute the mortgage object, which has an impact on the creditor. ${ }^{22}$ Concerning these weaknesses, the Chairman of AKPI stated that it is true that Law 37/2004 still has many flaws. However, the question is whether the PERPU Moratorium Law 37/2004 is issued later, the problem of the high number of bankcoruptcy during the pandemic, which also triggered by the weakness of Act 37/2004 can be resolved?

Before further assessing whether the moratorium is a solution during this pandemic, it is crucial to understand the meaning of the moratorium.

19 Bakti Siahaan, "Akibat Hukum Pernyataan Kepailitan terhadap Perseroan Terbatas", Pranata Hukum, Volume 3 Nomor 1, 2008, hlm. 69.

${ }^{20}$ Luthvi Ferbyka Nola, Loc.cit.

${ }^{21}$ Imanuel Rahmani, "Perlindungan Hukum Kepada Pembeli dalam Kepailitan Pengembang (Developer) Rumah Susun", Jurnal Hukum Bisnis Bonum Commune, Volume 1 Nomor 1, 2018, hlm. 87.

${ }^{22}$ Titie Syahnaz, "Akibat Hukum Kepailitan Terhadap kreditur Pemegang Hak Tanggungan dalam Eksekusi Hak Tanggungan", Jurnal Manajemen dan Bisnis Sriwijaya, Volume 16 Nomor 3, 2018, hlm. 162. 
According to the Big Indonesian Dictionary (KBBI), the moratorium is a suspension of debt payments based on the law to prevent the financial crisis from getting worse. ${ }^{23}$ Regarding the insistence on a moratorium on Act 37/2004 itself, the General Chairperson of the Indonesian Association of Curators and Administrators (AKPI), Dr. Jimmy Simanjuntak, S.H., M.H., stated in an official broadcast that the moratorium on Act 37/2004 means to suspend or temporarily stop the implementation of Act 37/2004..$^{24}$ The temporary suspension means that there is no longer a legal umbrella that protects the wheels of investment in Indonesia within a certain period of time. During the pandemic, Indonesia's investment wheel was supported by foreign investors who succeeded in helping Indonesia's economy recover during the pandemic. This is proven by the fact that foreign investment in the third quarter of 2020 has contributed $50.8 \%$ or Rp 106.1 trillion of investment realization that helped restore the Indonesian economy. 25 For foreign investors, one of the reasons for investing in Indonesia is the existence of Act $37 / 2004$. With the a quo law, foreign investors get a comprehensive security guarantee because if the debtor is unable to pay, there is a legal umbrella that provides solutions for both parties. ${ }^{26}$ Therefore, if the moratorium is carried out, there will be no guarantee of legal protection for foreign investors to invest in Indonesia, which can impact decreasing investment realization in Indonesia. The presence of the moratorium is actually a setback for the guarantee of the Indonesian economy because there is no guarantee for investors.

Regarding the weakness of Act 37/2004, this issue is actually not a new thing. Since mid-2020, the government has started discussing amendments to Act $37 / 2020 .{ }^{27}$ This means by discussing the amendments, the problem of the weakness of Act 37/2004 is interpreted as a problem with a temporary solution and a problem that requires a long-term solution. As the purpose of the moratorium is a temporary suspension and does not mean fixing it, in fact, if

\footnotetext{
${ }^{23}$ Kamus Besar Bahasa Indonesia (KBBI), "Moratorium", Badan Pengembangan dan Pembinaan Bahasa, Kementerian Pendidikan, Kebudayaan, Riset, dan Teknologi Republik Indonesia, diakses dari https://kbbi.kemdikbud.go.id/entri/moratorium.

${ }^{24}$ AKPI Official, "Pernyataan Dr. Jimmy Simanjuntak, S.H., M.H. (Ketua Umum AKPI)", AKPI Official Youtube Channel, 30 Agustus 2021, diakses dari https://www.youtube.com/watch?v=msTGscKJQtk.

25 Badan Koordinasi Penanaman Modal, "Realisasi Investasi Triwulan III 2020", Kementerian Komunikasi dan Informatika RI, 23 Oktober 2020, diakses dari https://kominfo.go.id/content/detail/32184/realisasi-investasi-triwulan-iii-2020/0/artikel_gpr.

${ }^{26}$ AKPI Official, loc cit.

${ }^{27}$ Mulyani Zulaeha, "Mengevaluasi Pembuktian Sederhana dalam Kepailitan sebagai Perlindungan terhadap Dunia Usaha di Indonesia", Jurnal Hukum Acara Perdata, Volume 1 Nomor 2, 2015, hlm. 176.
} 
the moratorium resolves the problems related to the weakness of Act 37/2004, it will not be the right solution because it is not long term. Reflecting on the basis for APINDO's demand on the government to issue a moratorium PERPPU, the main cause for this issue is actually the weakness in Act 37/2004. This means that the provisions in Act 37/2004 are not relevant to be applied during the COVID-19 pandemic, so they cannot minimize the number of bankruptcy applications. In this case, Indonesia needs a quick and temporary solution that can fix the parts that do not comply, not suspend the legal umbrella as a whole. Thus, as the moratorium on Act 37/2004 means temporarily suspending Act 37/2004 in its entirety and without providing specific improvements, it can be stated that the moratorium is not the right solution to overcome the high number of bankruptcies based on the weakness of Act 37/204 during the COVID-19 pandemic. Reflecting on other countries that have succeeded in reducing the number of bankruptcies during the COVID-19 pandemic, what has been done is to provide limitations on rights to existing regulations. In the case of problems in Indonesia, there is a need for restrictions on rights to Act 37/2004. The limitations of that right are regulated in the temporary measures on bankruptcy.

\section{B. The urgency of Temporary Measures on Bankruptcy in reducing the number of bankruptcies in Indonesia during the COVID-19 pandemic era}

Temporary measures are settings that allow flexibility in some issues to reduce certain potential risks and are applied within a specific time. ${ }^{28}$ The implementation is executed on a specific need of a problem. ${ }^{29}$ In the field of law, temporary measures are not a new thing. Temporary measures are used as special rules or guidelines in reducing the potential risk of a specific situation at a certain time. In the current COVID-19 pandemic, countries often use temporary measures to provide specific rules and/or guidelines to minimize the risk of a pandemic in the health, economic, and other sectors. ${ }^{30}$ Indonesia has implemented temporary measures, which was issued by the

\footnotetext{
${ }^{28}$ United States, “Temporary Measures Overview", U.S. Center for Safesport, 4 Mei 2020, diakses dari https://uscenterforsafesport.org/wp-content/uploads/2020/05/Temp-Measures-Overview-FAQ-May2020.pdf.

29 Ibid.

${ }^{30}$ Australia juga telah menerapkan dengan Temporary Relief for Financially Distressed Businesses untuk mengatasi krisis ekonomi pada masa pandemi COVID-19; Singapura mengeluarkan COVID-19 (Temporary Measures) Act 2020 untuk mengatur beberapa sektor di masa pandemi COVID-19 seperti perpajakan dan aturan kontraktual.
} 
Embassy of the Republic of Indonesia Belgrade, Temporary Measures to enter Indonesia Concerning the Recent Development of the COVID-19 Pandemic. ${ }^{31}$

Meanwhile, temporary measures on bankruptcy are temporary measures in the form of specific rules or instructions to regulate and provide instructions to minimize potential risks in bankruptcy that are carried out for a certain time. During the COVID-19 pandemic, many countries have implemented temporary measures on bankruptcy, for example, the Temporary Measures in Bankruptcy and Insolvency Laws in the Asia Pacific, which are applied to Hong Kong, India, Malaysia, New Zealand, Japan, Singapore, and South Korea. Australia has also implemented Temporary Relief for Financially Distressed Businesses. The fundamental reason for the implementation of temporary measures in each of these countries is the urgency to protect the economy by providing a safety net to the business sector in minimizing the impact of the economic crisis due to the COVID-19 pandemic. Meanwhile, the core of the regulation of temporary measures in each country is different. The substance follows the necessities and circumstances of each country. Temporary measures on bankruptcy in several countries have proven to be effective in reducing bankruptcy rates up to $64 \%$ during the COVID-19 pandemic. ${ }^{32}$ Chairman of AKPI, Jimmy Simanjuntak, stated that the moratorium is not a solution and the limitations of rights against Act 37/2004 can be accommodated in temporary measures. ${ }^{33}$ The contents of the temporary measures for bankruptcy in Indonesia can be in the form of whether there are provisions for temporary creditors who are not allowed to apply for PKPU and bankruptcy for a certain time, requirements that are complicated, and other things that need profound study from the government. ${ }^{34}$ The contents of the temporary measures for bankruptcy in Indonesia can be in the form of whether there are provisions for temporary creditors who are not allowed to apply for PKPU and bankruptcy for a certain time, requirements that are complicated, and other things that need profound study from the government. With temporary measures, Act 37/2004 remains a

\footnotetext{
${ }^{31}$ Republik Indonesia, "Temporary Measures to Enter Indonesia Concerning the Recent Development of the COVID-19 Pandemic", Embassy of the Republic of Indonesia in Beograd, The Republic of Serbia, 29 Desember 2020, diakses dari https://kemlu.go.id/belgrade/en/news/10274/temporary-measures-toenter-indonesia-concerning-the-recent-development-of-the-COVID-19-pandemic.

${ }^{32}$ Esther Lee, "The State of Nation: Bankruptcy and winding-up cases continued declining trend in 2020", The Edge Markets, 26 Juli 2021, diakses dari https://www.theedgemarkets.com/article/statenation-bankruptcy- and-windingup-cases-continued-declining-trend-2020.

${ }^{33}$ CNBC Indonesia Youtube Channel, "Asosiasi Kurator Sebut Moratorium PKPU Tidak Relevan, Ini Alasannya!", CNBC Indonesia, 30 Agustus 2020, diakses dari https://www.youtube.com/watch?v=w_UbZyEpj-Y. ${ }^{34} \mathrm{Ibid}$
} 
guarantee for investors. Several things during this pandemic need to be emphasized, such as restrictions that are made through temporary measures for a certain period of time. Recognizing the success of other countries in reducing the number of bankruptcies during the COVID-19 pandemic with temporary measures, as well as the analysis that stated a moratorium is not a solution, then temporary measures are more appropriate as a solution in overcoming the high number of bankruptcies in Indonesia during the COVID19 pandemic.

C. Prospects of Setting and Implementing Temporary Measures on Bankruptcy in Handling Bankruptcy in Indonesia in the COVID-19 Pandemic Era

I. Study on the Implementation of Temporary Measures on Bankruptcy in Other Countries

a. Singapore

The impact of the COVID-19 pandemic on the economy is felt by Indonesia and other countries in the world, including Singapore. Acknowledging this impact, Singapore issued a policy in the form of the COVID-19 (Temporary Measures) Act 2020 ("C19TMA"). C19TMA provides temporary assistance to individuals, companies, and other forms of business experiencing financial difficulties ${ }^{35}$. The temporary changes listed in C19TMA affect the Bankruptcy Act, The Companies and The Insolvency Act, Restructuring and Dissolution Act 2018 ("IRDA") for six months. Some temporary changes implemented include:

a) Changes to the period given until the debtor is declared "unable to pay" is extended to 6 months, from the previous 21 days";

b) Changes to the financial threshold for individual and corporate bankruptcy by increasing it to $\$ 60,000$ in bankruptcy applications, from the previous $\$ 15,000$;

c) Changes to the debt threshold held to be able to apply for a Debt Repayment Scheme by increasing it to $\$ 250,000$, from the initial $\$ 100,000$; and

\footnotetext{
35 Aurelio Gurrea-Martinez dan Samuel Loh, "Singapore's Legal and Economic Response to the COVID-19 Crisis: The Role of Insolvency Law and Corporate Workouts", International Corporate Rescue, Volume 17 Nomor 4, 2020, hlm. 293.
} 
d) Changes to the financial threshold for company closure by increasing it to $\$ 100,000$ in the closing request. ${ }^{36}$

If the conditions above have not been fulfilled, creditors are prohibited from starting the bankruptcy process to pay off debts. In addition to changes to certain thresholds in various existing laws, other changes applied to bankruptcy cases during the COVID-19 pandemic in Singapore are related to the inability to carry out an obligation in a contract. Based on C19TMA, if the agreement is effective from 25 March 2020 or renewed before 25 March 2020 (or automatically renewed on/after March 2020), the obligations in the contract must be carried out on/after February 2020. However, if certain circumstances happened affected by the pandemic COVID-19, one of the parties becomes unable to carry out the obligations in the contract, then the party has the right to submit a 'notice' for waivers to the other party in the agreement. However, if certain circumstances happened affected by the pandemic COVID-19, one of the parties becomes unable to carry out the obligations in the contract, then the party has the right to submit a 'notice' for waivers to the other party in the agreement. The notification by one party means that the other party is prohibited from taking specific actions, including filing for bankruptcy and bankruptcy (including regulatory or judicial application schemes) against the party providing the waiver 'notice'. The submission of bankruptcy by the other party to the contract can only be made after the expiration of the recovery period or when the 'notice' relating to relief has been withdrawn by the party providing the 'notice' or if the 'notice' is deemed invalid. ${ }^{37}$

It is not only the issue of filing for bankruptcy that is of concern to the Government of Singapore but also the issue of corporate restructuring. The Bankruptcy, Restructuring, and Dissolution (Amendment) Bill was submitted on October 5, 2020, which regulates the Simplified Insolvency Program. The Simple Bankruptcy Program is intended to help micro and small companies with more than two million in debt that need support to restructure their debts. The expected goal of this program is that the government can rehabilitate

\footnotetext{
${ }^{36}$ Supreme Court Singapore, "Impact of COVID-19 (Temporary Measures) Act 2020 on Bankruptcy and Winding Up Applications", Supreme Court Singapore, 23 Oktober 2020, diakses dari https://www.supremecourt.gov.sg/quick-links/visitors/COVID-19/impact-of-COVID-19-(temporarymeasures)-act-2020-on-bankruptcy-and-winding-up-applications.

${ }^{37}$ Jacqueline Teo, An overview of temporary measures relating to Bankruptcy and Insolvency laws in response to the COVID-19 pandemic in the Asia Pacific Region, Mackrell International, London, 2020, hlm. 12-13.
} 
these companies or dissolve the company if it is deemed no longer feasible. ${ }^{38}$

b. Malaysia

Similar to Singapore, Malaysia also has a bankruptcy relaxation policy to reduce the number of bankruptcy filings. Malaysia's bankruptcy relaxation policy is known as the Temporary Measures for Reducing the Impact of Coronavirus Disease 2019 (COVID-19) Act 2020 ("COVID Act") passed on 23 October 202039. However, there are differences with Singapore about the validity period of this policy. A similar policy in Singapore is valid for six months and can be extended later by the government if circumstances require such an extension. Meanwhile, Malaysia's COVID Act can last up to 2 years. The minimum debt threshold for filing for bankruptcy was also increased from the initial RM50,000 to RM100,00040. The increase in the threshold indicates a significant decrease in filing for bankruptcy, from 12,051 cases in 2019, 8,351 cases in 2020, and 2,954 cases in the first four months of 2021. ${ }^{41}$

The number of company closures due to unpaid debts caused by the economic impact of the COVID-19 pandemic was also acknowledged by the Malaysian Government. Therefore, temporary protection against company closures during the pandemic is also listed in the COVID Act by regulating the postponement of loan payments for 14 months until the end of December 202142. This policy also had a meaningful impact, as seen from a vast decrease in the number of proposed closures for companies and voluntary company closures. Concerning closures proposed by creditors against companies, in 2019, the number of cases reached 1,966 then decreased in 2020 to 1,190 cases, and in the first four months of 2021 (January - April), cases only stood at 192. Likewise, for voluntary company closures, the number of cases in

${ }^{38} \mathrm{Ibid}, \mathrm{hlm} .13$.

39 Rohana Abdul Rahman, "Overview of the Temporary Measures for Reducing the Impact of Coronavirus Disease 2019 (COVID-19) Act 2020", International Journal of Law, Government and Communication (IJLGC), Volume 5 Nomor 21, 2020, hlm. 221.

${ }^{40}$ Amanda Wong Yoke Ting, An overview of temporary measures relating to Bankruptcy and Insolvency laws in response to the COVID-19 pandemic in the Asia Pacific Region, Mackrell International, London, 2020, hlm. 6.

${ }^{41}$ Esther Lee, Loc.Cit.

${ }^{42}$ Sheba Gumis, "Malaysia: Covid 19: Part II Of The Temporary Measures Act 2020 Extended To 31 December 2021", Mondaq, 7 Juli 2021, diakses dari https://www.mondaq.com/litigation-contracts-andforce-majeure/ 1088924/COVID-19-part-ii-of-the-temporary-measures-act-2020-extended-to-31december-2021. 
2019 was 1,216 but decreased in 2020 to 863 cases and 503 cases in the first four months of 2021 (January - April). ${ }^{43}$

The presence of Malaysia's COVID Act is also supported by other policies that encourage business continuity, such as automatic suspension of all loan payments by banking institutions to all individuals and Small and Medium Enterprises (SMEs) within a period of 6 months, the presence of a Special Relief Facility (SRF) financing facility. ) and financial grants for MSMEs, Accelerated Capital Allowance ("ACA"), which was intended to help cover production costs for industrial machinery and equipment for ten months from March 1, 2020 - December 31, 2020, various tax breaks, cuts in electricity and rental costs, to employee wage subsidy. ${ }^{44}$

II. Prospects of Implementing Temporary Measures on Bankruptcy in Indonesia

OJK Regulation Number 11/POJK.03/2020 concerning National Economic Stimulus as a Countercyclical Policy for the Impact of the Spread of Coronavirus Disease 2019 as amended through OJK Regulation Number 48/POJK.03/2020 is a policy issued by the Government of Indonesia in response to the economic impact of the COVID-19 pandemic ${ }^{45}$. However, the problem is that the OJK Regulation mainly focuses on credit restructuring, which is left to the policies of each bank. OJK regulation positively does not protect debtors who have problems paying debts to non-bank creditors/other financial services. In addition, the restructuring provisions in the OJK Regulation are flexible, and the OJK sets no clear threshold. Of course, this arrangement does not significantly reduce bankruptcy filings as expected by the Government. The general chairman of the Indonesian Association of Curators and Administrators (AKPI), Jimmy Simanjuntak, said that bankruptcy and PKPU applications had increased by up to $50 \%{ }^{46}$ The legal vacuum that exists in the current bankruptcy relaxation is suspected to be one of the causes. The absence of laws and regulations governing the relaxation of bankruptcy means that Act 37/2004 applies without any intervention.

\footnotetext{
${ }^{43}$ Lee, Loc.Cit.

${ }_{44}^{4}$ Ting, Op.Cit., hlm. 7.

${ }^{45}$ Raka Dewantara, "Politik Hukum Pengaturan Mengenai Tindakan Pencegahan Non Performing Loan pada Bank dalam Masa Pandemik dengan Pendekatan Konsep Bifurkasi Hukum", Jurnal Bina Mulia Hukum, Volume 6 Nomor 1, 2021, hlm. 69.

${ }^{46}$ Heriani, Loc.Cit.
} 
Easy bankruptcy filings are also suspected to be the cause of the high number of bankruptcy in the pandemic era ${ }^{47}$, Easy bankruptcy filings are also suspected to be the cause of the high number of bankruptcy in the pandemic era, in addition to the absence of laws and regulations that provide a clear and firm legal umbrella for bankruptcy relaxation. Based on Article 2 paragraph (1) of Act 37/2004, it is stated that the requirements for filing bankruptcy are that the debtor has at least two creditors or more, and there is one debt that is due and can be collected. This provision is considered easy because if it has been proven that the party proposed for bankruptcy has met these requirements, the judge is obliged to decide on bankruptcy based on Article 8 paragraph (4) of Act 37/2004. Referring to Article 8 paragraph (7) of Act 37/2004, the bankruptcy decision is also instantaneous, which means that the execution of the decision can be carried out even though there are legal remedies submitted.

Examining the implementation in various countries that execute temporary measures on bankruptcy supported by the provision of other stimuli in their laws and regulations, such as Singapore and Malaysia, there are several advantages that can be obtained if this is also applied in Indonesia during the COVID-19 pandemic to economic recovery. going well and stable. Some of these advantages include:

a. Significant reduction in the number of bankruptcy and PKPU filed in court;

b. Cost efficiency for creditors and debtors in solving debt problems;

c. Keeping businesses or eligible companies from closing;

d. Maintaining the business ecosystem and the country's economy;

e. Strengthening debtor companies to be productive by taking other trading steps within the given relaxation time to avoid bankruptcy;

f. Is a middle way (win-win solution) for both debtors and creditors not to experience too large a loss; and

g. Provide equal protection to debtors with creditors of banks/other financial service institutions and debtors with creditors of nonbanks/other financial service institutions

Examining the advantages of temporary measures on bankruptcy applied in countries in the world, which are primarily listed in these

${ }^{47}$ Nola, Op.Cit., hlm. 2-3. 
measures and can also be the substance of similar measures in Indonesia, as follows:

a) The lower threshold of the nominal debt that cannot be paid from one of the creditors by reviewing the nominal assets that the company still owns;

b) The nominal lower threshold of assets still owned by the company by reviewing the company's valuation;

c) Allowance of the time until the debtor is declared "unable to pay";

d) Providing economic stimulus so that companies can operate to cover the value of debt; and

e) Determination of the validity period of temporary measures on bankruptcy.

If temporary measures on bankruptcy in other countries are regulated by law, Indonesia can also regulate it. The law is a solid legal product to provide a clear legal political direction compared to different laws and regulations under the law. However, the obstacle is that the 20202024 National Legislation Program (Prolegnas) has been agreed upon, there are 246 bills, and 33 bills are the 2021 Priority Prolegnas Bill. So, Acknowledging the pandemic's impact on the economy currently taking place, the law regarding temporary measures on bankruptcy cannot be postponed until 2025 and needs to be established and ratified immediately. The solution that can be done is to issue the regulation in the form of a Government Regulation in Lieu of Law ("PERPU"). Article 22 paragraph (1) of the 1945 Constitution (“UUD 1945”) regulates:

"Should exigencies compel, the President shall have the right to establish government regulations in lieu of laws."

Similar requirements are also stated in Article 1 point 4 of the Act of the Republic of Indonesia Number 12 of 2011 concerning the Establishment of Legislation ("Law 12/2011"):

"Government Regulation in Lieu of Law is a statutory regulation stipulated by the President in matters of urgency that compel."

The clause "exigencies" becomes the emphasis on whether these conditions are fulfilled so that the PERPU regarding temporary measures on bankruptcy can be issued. Based on the Constitutional Court Decision 
Number 138/PUU-VII/2009, there are three aspects to determine the state of "exigencies" so that the President can determine the PERPU:

a) There is an urgent need to resolve legal issues quickly based on the Act;

b) There is a legal vacuum due to the absence of required Law, or there is already an inadequate Law; and

c) The legal vacuum cannot be overcome by making laws through the standard procedure through the National Legislation Program because it will take quite a long time while the urgent situation requires certainty to be resolved.

Recognizing the skyrocketing state of bankruptcy filings and PKPU, these three parameters have been fitted by the fact that the number of bankruptcy and PKPU skyrocketed 50\% in the COVID-19 pandemic era. Moreover, no legal product can prevent the easiness of filing bankruptcy based on Act 37/2004. The only existing regulation in response to the economic impact of the COVID-19 pandemic is OJK Regulation Number 48/POJK.03/2020 jo. OJK Regulation Number 11/POJK.03/2020 cannot reduce the number of bankruptcies and PKPU because the rules are too flexible and have a narrow scope, solely covering bank creditors and other financial service institutions. This legal vacuum also cannot be overcome by making laws through the usual procedure by waiting for the Prolegnas 'queue'. This is because the economic impact of the COVID-19 pandemic is still ongoing and is eroding the business ecosystem in Indonesia, one of which is due to the large number of business closures that are considered feasible due to bankruptcy filings by creditors. The formation of the next Prolegnas will be carried out in 2025, which means there are still four years left. The pandemic, which has only lasted for approximately a year, has resulted in an increase in bankruptcy and PKPU by 50\%, If the formation of a legal umbrella for the relaxation of bankruptcy is delayed for another four years, this percentage will continue to increase significantly and have a massive adverse impact on the economic ecosystem in Indonesia.

\section{CONCLUSION}

The bankruptcy moratorium and PKPU in Act 37/2004 as regulations to resolve the problem of the high number of bankruptcy and PKPU in Indonesia are not the right solution. One of the reasons is that the moratorium does not provide fair benefits for both parties (a win-win solution). The most benefitted party is only the debtor, while creditors can only wait for the moratorium and 
file bankruptcy. These regulations also causes uncertainties for investors to invest in Indonesia because there is no guarantee. Regulating temporary measures on bankruptcy in PERPU is the right solution. Temporary measures on bankruptcy can provide fair benefits for both parties. Bankruptcy can still be filed but with certain limitations and a stimulus to minimize the potential risk of bankruptcy in the COVID-19 pandemic era. Temporary measures on bankruptcy are urgent to be implemented in Indonesia, given the increase in the number of bankruptcy applications and PKPU, which increased by $50 \%$ in the pandemic era. It has been proven in various countries that temporary measures on bankruptcy can reduce the bankruptcy rate by up to $64 \%$. Concerning the legal vacuum of efforts to relax bankruptcy in Indonesia, where currently there is only OJK Regulation Number 48/POJK.03/2020 jo. OJK Regulation Number 11/POJK.03/2020, which regulates the obligation to provide stimulus policies by banks/other financial service institutions, does not specifically regulate bankruptcy, including non-bank creditors/financial service institutions. So, with the urgency that forces the business ecosystem in Indonesia due to the high number of bankruptcies, temporary bankruptcy measures need to be regulated in PERPU.

\section{DECLARATION OF CONFLICTING INTERESTS}

None

\section{FUNDING INFORMATION}

None

\section{ACKNOWLEDGEMENT}

The writing was carried out well thanks to the support of various parties, therefore the authors would like to thank Shahyb Handyanto who has assisted in the review, and all Lecturers of the Department of Law, Faculty of Law, Gadjah Mada University.

\section{REFERENCES}

Ayuni, S, dkk. (2020). Analisis Hasil Survei Dampak COVID-19 Terhadap Pelaku Usaha Jilid II. Jakarta: Badan Pusat Statistik Republik Indonesia.

Badan Koordinasi Penanaman Modal. (Oktober, 2021). “Realisasi Investasi Triwulan III 2020", Kementerian Komunikasi dan Informatika RI, 23 Oktober 2020, diakses dari https://kominfo.go.id/content/detail/32184/realisasiinvestasi-triwulan-iii-2020/0/artikel_gpr. 
CNBC Indonesia Youtube Channel, (Agustus, 2021). "Asosiasi Kurator Sebut Moratorium PKPU Tidak Relevan, Ini Alasannya!", CNBC Indonesia, 30 Agustus 2020, diakses dari https://www.youtube.com/watch?v=w_UbZyEpj-Y.

Dewantara, R. (2021). Politik Hukum Pengaturan Mengenai Tindakan Pencegahan Non Performing Loan pada Bank dalam Masa Pandemik dengan Pendekatan Konsep Bifurkasi Hukum. Jurnal Bina Mulia Hukum, 6(1), 66-83.

Gumis, S. (Juli, 2021). "Malaysia: Covid 19: Part II Of The Temporary Measures Act 2020 Extended To 31 December 2021", Mondaq, 7 Juli 2021, diakses dari https:/www.mondaq.com/litigation-contracts-and-forcemajeure/1088924/COVID-19-part-ii-of-the-temporary-measures-act-2020extended-to-31-december-2021.

Gurrea-Martinez, A. \& Loh, S. (2020). Singapore's Legal and Economic Response to the COVID-19 Crisis: The Role of Insolvency Law and Corporate Workouts. International Corporate Rescue, 17(4), 292-297.

Heriani, F. (Agustus, 2020). "Perkara Kepailitan dan PKPU Meningkat 50 Persen Selama Pandemi", Hukum Online, 31 Agustus 2020, diakses dari https://www.hukumonline.com/berita/baca/lt5f4ce322c779b/perkarakepa ilitan-dan-pkpu-meningkat50-persen-selama-pandemi/

Kamus Besar Bahasa Indonesia (KBBI), "Moratorium", Badan Pengembangan dan Pembinaan Bahasa, Kementerian Pendidikan, Kebudayaan, Riset, dan Teknologi Republik Indonesia, diakses dari https://kbbi.kemdikbud.go.id/entri/moratorium.

Lee, E. (Juli, 2021). "The State of Nation: Bankruptcy and winding-up cases continued declining trend in 2020", The Edge Markets, 26 Juli 2021, diakses dari https://www.theedgemarkets.com/article/state-nationbankruptcy-and-windingup-cases-continued-declining-trend-2020.

Maesaroh. (September, 2021). “Asosiasi Pengusaha Desak Jokowi Terbitkan Perppu Moratorium PKPU”, Katadata.co.id, 7 September 2021, diakses dari https://katadata.co.id/maesaroh/berita/61377c61ba3e2/asosiasipengusaha-desak-jokowi-terbitkan-perppu-moratorium-pkpu.

Mangun, U., Asiesteus, S., \& Varida, N. (2017). Kepailitan dan Penundaan Kewajiban Pembayaran Utang Studi Hukum dalam Rangka Penyusunan Naskah Akademik Rancangan Undang-Undang Nomor 37 Tahun 2004. 
Jakarta: Badan Penelitian dan Pengembangan Hukum dan HAM Kementerian Hukum dan HAM Republik Indonesia.

Nola, L. F. (2020). Dampak Kemudahan Pengajuan Pailit di Masa Pandemik COVID-19. Info Singkat, XII (18), 1-6.

AKPI Official. (Agustus, 2021). "Pernyataan Dr. Jimmy Simanjuntak, S.H., M.H. (Ketua Umum AKPI)", AKPI Official Youtube Channel, 30 Agustus 2021, diakses dari https://www.youtube.com/watch?v=msTGscKJQtk.

Siregar Setiawan Manalu Partnership. (September, 2021). “Mempertanyakan Kegentingan Moratorium PKPU”, SSMP, 3 September 2021, diakses dari https://www.ssmp.co/assets/pdf/mempertanyakan-kegentinganmoratorium-PKPU.pdf.

Rahman, R. (2020). Overview of the Temporary Measures for Reducing the Impact of Coronavirus Disease 2019 (COVID-19) Act 2020. International Journal of Law, Government and Communication (IJLGC), 5(21), 220-227.

Rahmani, I. (2018). Perlindungan Hukum Kepada Pembeli dalam Kepailitan Pengembang (Developer) Rumah Susun. Jurnal Hukum Bisnis Bonum Commune, 1(1), 73-88.

Republik Indonesia, (Desember, 2020). “Temporary Measures to Enter Indonesia Concerning the Recent Development of the COVID-19 Pandemic", Embassy of The Republic of Indonesia in Beograd, The Republic of Serbia, 29 Desember 2020, diakses dari https://kemlu.go.id/belgrade/en/news/10274/temporary-measures-toenter-indonesia-concerning-the-recent-development-of-the-COVID-19pandemic.

Hendriawan, M. R., Suratman, \& Rokhim, A. (2021). Penundaan Kewajiban Pembayaran Utang Untuk Mencegah Debitur Pailit Akibat Pandemi COVID-19 Berdasarkan Hukum Kepailitan. Dinamika Jurnal Ilmiah Ilmu Hukum, 27(2), 283-296.

Sahbani, A. (September, 2021). "Respons MA Terkait Rencana Moratorium PKPU dan Kepailitan", Hukum Online, 2 September 2021, diakses dari https://www.hukumonline.com/berita/baca/lt612fbd1f1bfc3/responsma-terkait-rencana-moratorium-pkpu-dan-kepailitan?page=all.

Siahaan, B. (2008). Akibat Hukum Pernyataan Kepailitan terhadap Perseroan Terbatas. Pranata Hukum, 3(1), 63-75.

Supreme Court Singapore. (Oktober, 2020). "Impact of COVID-19 (Temporary Measures) Act 2020 on Bankruptcy and Winding Up Applications", Supreme Court Singapore, 23 Oktober 2020, diakses dari https://www.supremecourt.gov.sg/quick-links/visitors/ COVID- 
19/impact-of-COVID-19-(temporary-measures)-act-2020-onbankruptcy-and-winding-up-applications.

Syahnaz, T. (2018). Akibat Hukum Kepailitan Terhadap kreditur Pemegang Hak Tanggungan dalam Eksekusi Hak Tanggungan. Jurnal Manajemen dan Bisnis Sriwijaya, 16(3), 154-163.

Teo, J. (2020). An overview of temporary measures relating to Bankruptcy and Insolvency laws in response to the COVID-19 pandemic in the Asia Pacific Region. London: Mackrell International.

Ting, A. (2020). An overview of temporary measures relating to Bankruptcy and Insolvency laws in response to the COVID-19 pandemic in the Asia Pacific Region. London: Mackrell International.

United States. (Mei, 2021). "Temporary Measures Overview”, U.S. Center for Safesport, 4 Mei 2020, diakses dari https://uscenterforsafesport.org/wpcontent/uploads/2020/05/Temp-Measures-Overview-FAQ-May2020.pdf.

Zulaeha, M. (2015). Mengevaluasi Pembuktian Sederhana dalam Kepailitan sebagai Perlindungan terhadap Dunia Usaha di Indonesia. Jurnal Hukum Acara Perdata, 1(2), 171-187. 


\section{ABOUT AUTHOR(S)}

Cintya Sekar Ayu P, born in Yogyakarta, June 28, 2000, is a 2019 Faculty of Law student at Gadjah Mada University focusing on Business Law. Active in various academic and non-academic activities, such as being the Head of Intellectual Property Division at the Business Law Community, Faculty of Law UGM, winning paper presentation competitions, writing legal journals and as an internal Legal Officer at a state-owned bank and legal internal at a legal startup. Can be contacted through e-mail cintyasekarayup@mail.ugm.ac.id.

Octa Nadia Mellynda, born in Yogyakarta, October 1, 2000, is a 2018 Faculty of Law student at Gadjah Mada University focusing on criminal law. Active in various academic and non-academic activities, such as being the Head of Competition Division for the 2020 period at the Speech and Law Debate Society, Faculty of Law UGM, becoming a research assistant, winning legal essay competitions and legal debates, and a legal intern in government agencies, firms law and corporation. 